\title{
Neonatal Graves Disease
}

National Cancer Institute

\section{Source}

National Cancer Institute. Neonatal Graves Disease. NCI Thesaurus. Code C131433.

Graves disease in the neonate resulting from transplacental passage of thyrotropin receptor antibody. 